\title{
Zooplankton of 15 lakes in the Southern Central Alps: comparison of recent and past (pre-ca 1850 AD) communities
}

\author{
Marina MANCA* and Michele ARMIRAGLIO \\ C.N.R. Istituto per lo Studio degli Ecosistemi, L.go Tonolli 50, 28922 Verbania Pallanza, Italy \\ *e-mail corresponding author: m.manca@iii.to.cnr.it
}

\begin{abstract}
We report the results of a study on modern zooplankton community as well as on Cladocera sub-fossil remains from 15 high altitude lakes in the Italian Central-Southern Alps, aimed at investigating changes after $19^{\text {th }}$ Century industrialisation. Present-day communities were compared to those of the pre-industrial period (approximately pre-1850 AD). Numerical analysis suggests a relationship between environmental variables, such as pH or total phosphorus, and the cladoceran community structure. However, as found in previous studies, another important environmental variable not included in numerical analysis, is presence or absence of fish. Arctodiaptomus alpinus was not found at pH levels lower than 6.21, while Daphnia lacked from lakes where fish were regularly introduced. Daphnia re-colonised the today fish-less Lago Paione Inferiore, whereas in the past, with a regular introduction of fish, only rotifers and a few Cyclops were found. The re-colonisation is interpreted by regarding the three Paione lakes as parts of a cascade system, where a transport from the upper Lago Paione Superiore to the lower Lago Paione Inferiore can take place, and the sediments represent a kind of an "egg bank".
\end{abstract}

Key words: zooplankton, sediments, alpine lakes, industrialisation

\section{INTRODUCTION}

The present study is a part of a Project funded by the European Union (EMERGE, European Mountain lakes Ecosystem: Regionalisation, diaGnostic \& socioeconomic Evaluation). The project is designed to support water Framework Directive with reference to lakes and focussed on: 1) assessing the chemical and biological status of remote mountain lakes through Europe; 2) establishing reference conditions for each site using historical source and paleolimnological methods; 3) upscaling the knowledge from single sites or regions; 4) assessing the extent to which climate variability, separately from and in combination with pollutant stresses, influences the status of these lakes. It concerns about 300 lakes in 13 "Lake districts" from 15 Countries, selected to be above (in the mountains) or beyond (in the arctic regions) the local timberline, and catchment undisturbed by human activity.

Indeed, air pollution has changed the recent history of many mountain lakes (Lami et al. 2000). We report here the results on present-day zooplankton communities as well as on Cladocera sub-fossil remains from 15 lakes in Western- Central (Pennine and Lepontine) Southern Alps only. The aim was that of investigating changes in the community during the past $c a 150$ years, i.e. pre- and after the $19^{\text {th }}$ Century industrialisation. These results will be then elsewhere combined with data (e.g. metals, organic pollutants, and biota) to classify sites into ecotypes along the main geographical and environmental gradients within Europe.

\section{SAMPLING SITES}

The lakes are located in the western-central part of the Italian Alps, in the so-called Central-Southern district of the EMERGE Project (Fig. 1). They are all included in the Lago Maggiore catchment basin. Altitude ranges between $1910 \mathrm{~m}$ a.s.l. (L. Muino Inferiore) and $2422 \mathrm{~m}$ a.s.l. (L. Sfondato). Acidic rocks prevail, with gneiss and schists; only three lakes (L. Boden Inferiore, L. Boden Superiore, and L. Matogno) are located in areas where carbonate rocks are most abundant. More detailed information on their physiographic and foodweb characteristics are reported in Lami et al. (2000).

\section{MATERIALS AND METHODS}

Sampling was carried out in September-early October 2000, when the lakes are usually ice-free and Cladocera are well represented; despite this, temperatures were low in some lakes (below $9{ }^{\circ} \mathrm{C}$ ), and one lake (L. Sfondato) was still almost entirely ice-covered at the sampling date.

$\mathrm{pH}$, taken as the average value along the water column, was almost uniformly distributed between 5.58 (L. Sfondato) and 7.98 (L. Boden Inferiore, Tab. 1). Total alkalinity ranged between $0 \mu \mathrm{eq} \mathrm{l}^{-1}$ (L. Sfondato and L. Grande) and $756 \mu$ eq $1^{-1}$ (L. Matogno). Total phosphorus concentration was very low, the highest value being around $7 \mu \mathrm{g} \mathrm{P} \mathrm{l}^{-1}$ (L. Muino Inferiore).

Two zooplankton samples were collected on each date, a qualitative (40 $\mu \mathrm{m}$ net, vertical as well as horizontal hauls), and a quantitative one $(200 \mu \mathrm{m}$ Apstein type plankton net, vertical hauls along the entire water 


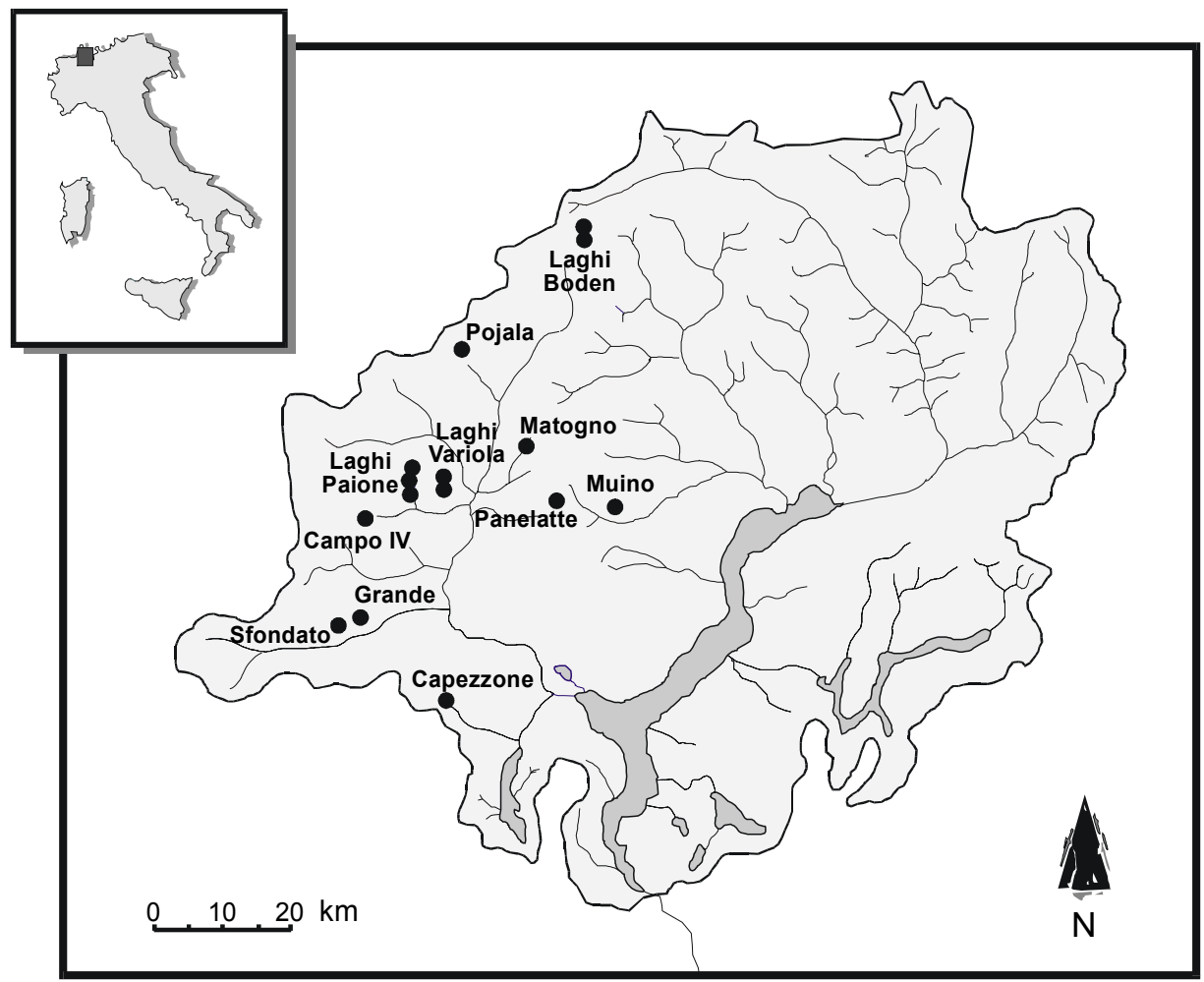

Fig. 1. Sampling sites in the Italian Western and Central Alps, all included in Lago Maggiore catchment area (also shown).

Tab. 1. Main physical and chemical characteristics of the sampled lakes (arranged in increasing $\mathrm{pH}$ order; data refer to the same date of zooplankton and sediment samplings).

\begin{tabular}{|c|c|c|c|c|c|c|c|c|c|}
\hline & $\begin{array}{l}\text { Max. depth } \\
\text { (m) }\end{array}$ & $\begin{array}{l}\text { Lake area } \\
\left(\mathrm{km}^{2}\right)\end{array}$ & $\begin{array}{l}\text { Conductivity } \\
\left(20^{\circ} \mathrm{C} \mu \mathrm{S} \mathrm{cm}^{-1}\right)\end{array}$ & $\begin{array}{l}\text { Total Alk. } \\
\left(\mu \text { eq } 1^{-1}\right)\end{array}$ & $\begin{array}{c}\mathrm{K}^{+} \\
\left(\mathrm{mg} \mathrm{l}^{-1}\right)\end{array}$ & $\begin{array}{c}\mathrm{NO}_{3}^{-} \\
\left(\mu \mathrm{g} \mathrm{N}^{-1}\right)\end{array}$ & $\begin{array}{c}\mathrm{Si} \\
\left(\mathrm{mg} \mathrm{l}^{-1}\right)\end{array}$ & $\begin{array}{c}\mathrm{TP} \\
\left(\mu \mathrm{g} \mathrm{P} \mathrm{l}^{-1}\right)\end{array}$ & $\mathrm{pH}$ \\
\hline Sfondato & 3 & 0.475 & 8.5 & 0 & 0.12 & 310 & 0.69 & 2 & 5.58 \\
\hline Grande & 6 & 0.751 & 7.3 & 0 & 0.10 & 215 & 0.58 & 1 & 5.73 \\
\hline Paione Superiore & 12 & 0.653 & 9.0 & 3 & 0.27 & 261 & 0.48 & 4 & 3.02 \\
\hline Variola Inferiore & 4 & 0.689 & 9.9 & 16 & 0.29 & 169 & 0.57 & 2 & 6.21 \\
\hline Variola Superiore & 4 & 0.903 & 10.5 & 17 & 0.35 & 215 & 0.51 & 4 & 6.31 \\
\hline Muino & 2 & 0.1 & 9.8 & 32 & 0.15 & 125 & 1.26 & 7 & 6.42 \\
\hline Paione Medio & 5 & 0.735 & 12.8 & 34 & 0.47 & 395 & 0.96 & 5 & 6.53 \\
\hline Paione Inferiore & 14 & 0.868 & 13.1 & 39 & 0.39 & 380 & 0.80 & 2 & 6.65 \\
\hline Capezzone & 7 & 0.94 & 22.4 & 138 & 0.14 & 304 & 0.92 & 4 & 6.83 \\
\hline Panelatte & 5 & 0.56 & 18.2 & 113 & 0.23 & 280 & 1.15 & 5 & 7.11 \\
\hline Pojala & 16 & 5.696 & 33.1 & 251 & 2.20 & 20 & 0.50 & 6 & 7.19 \\
\hline Campo IV & 7 & 0.751 & 49.7 & 381 & 0.54 & 228 & 1.38 & 2 & 7.35 \\
\hline Boden Superiore & 6 & 2.831 & 48.9 & 415 & 0.74 & 189 & 0.80 & 2 & 7.81 \\
\hline Matogno & 15 & 3.031 & 80.2 & 756 & 0.97 & 147 & 0.85 & 4 & 7.96 \\
\hline Boden Inferiore & 7 & 5.879 & 57.3 & 523 & 0.94 & 81 & 0.73 & 2 & 7.98 \\
\hline
\end{tabular}

column), for crustacean zooplankton only. A short core was also collected from each lake with a gravity corer from the deepest area; the recent Cladocera communities ( $c a$ last 5 years) were reconstructed from an analysis of the top $0.5-1 \mathrm{~cm}$ sediment section, while the 15-17 $\mathrm{cm}$ levels referred to the pre-industrial period. Carbonaceous particle fly ash screening was used to ensure the bottom samples were of pre-industrial age (Guilizzoni et al. 1996) (EMERGE Protocol). Chronology was approximately derived by previous studies (cf. e.g. Guiliz- zoni et al. 1992) on some of these lakes. We usually counted the zooplankton samples entirely; only in two cases an analysis of $10 \%$ of the total was sufficient to obtain good estimates of species abundance.

Cladocera sub-fossil remains were counted on $c a 3 \mathrm{~g}$ wet weight of sediment, after treating the sample with the method proposed by Frey (1986), and following the recommendations of the EMERGE Protocol. At least 200 remains were counted and identified following Frey (1958 and 1960) at magnifications between 100 and 
$200 \times$. We calculated species richness (taken as the number of taxa found) and Shannon-Weaver diversity index of the past and present Cladocera assemblages.

By applying techniques of numerical analysis (PCA and RDA), we tried to classify the recent Cladocera communities of the lakes and the environmental parameters, as well as to describe changes in community structure during $19^{\text {th }}$ and $20^{\text {th }}$ Century. We used the program CANOCO in the Windows version (CANOWIN) (Charles et al. 1994; Ter Braak et al. 1987).

\section{RESULTS AND DISCUSSION}

Lake Paione Medio was excluded from the analysis because the 15-17 layer did not represent the pre-industrial period. This level was in fact rich in carbonaceous particles of anthropogenic origin (N.L. Rose, pers. comm.).

Species mainly represented in the zooplankton samples of the lakes (only crustacea) were, in order of abundance, Cyclops abyssorum (the ecomorph C. tatricus included), Daphnia longispina, and Arctodiaptomus alpinus. In one case (L. Muino Inferiore) also the predator Heterocope saliens was found. In addition to these, other 7 species were counted (11 as total).

Arctodiaptomus alpinus, which is reported as a species sensitive to low $\mathrm{pH}$ levels (Fott et al. 1994), was not found in lakes with $\mathrm{pH}$ levels below 6.21, whereas Daphnia was not found at $\mathrm{pH}<5.73$ and in lakes where fish were regularly introduced.

All cladoceran taxa found in the zooplankton water samples were also recovered from recent sediments; the most represented were, in order of abundance, Alona affinis, Alona quadrangularis, Chydorus sphaericus and Acroperus harpae. While during the pre-1850 period, the two congeneric species $A$. affinis and A. quadrangularis had similar levels of abundance, in present-day communities the former dominates (Fig. 2). In the recent communities, Acroperus harpae and Chydorus sphaericus are almost equally important, while in the pre-industrial period, the latter was the third most abundant species.

The community of most acidified lakes $(\mathrm{pH} \leq 6.3$ ) has a lower diversity in the recent period than in the pre-industrial one (Fig. 3); such a decline is mainly due to the disappearance of species which also in the past were rare. Two lakes were not taken into account for diversity estimates, namely, L. Muino Inferiore, where a little dike was built close to the outlet (so we might assume an increase in its recent water level compared to the past), and L. Campo, because only Alona affinis was found in recent sediments.

The results of numerical analysis (PCA and RDA) on recent $(\mathrm{t})$ sediments are reported in tables 2-3 and figures $4-5$. The horizontal axis representing a species or an environmental variable refers to the highest percentage of total variance explained. Each species/environmental variable is represented by an arrow, which determines a direction or axis in the diagram; the longer the arrows the higher the importance of the species/environmental variable for the distribution of the data.

PRE-ca.1850

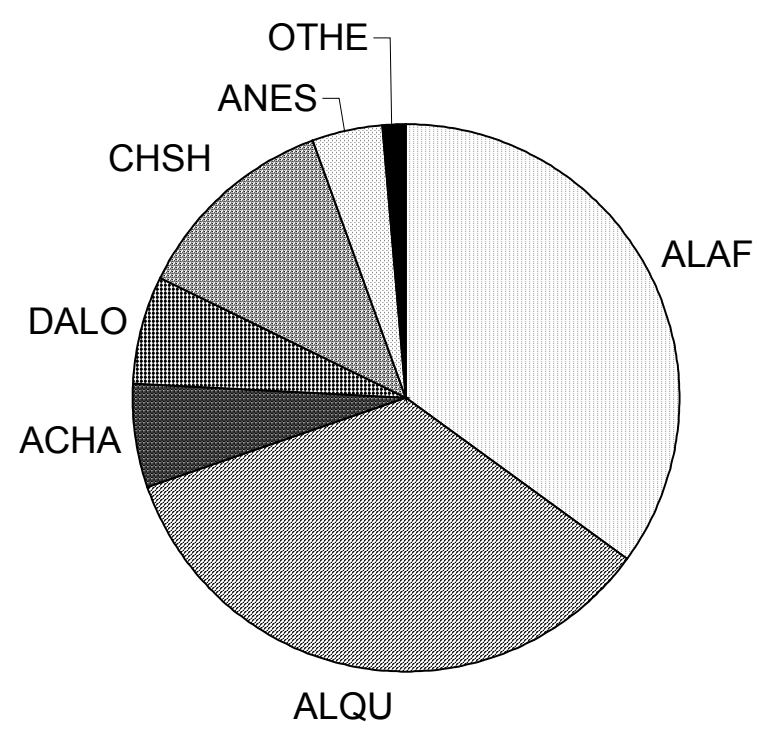

RECENT

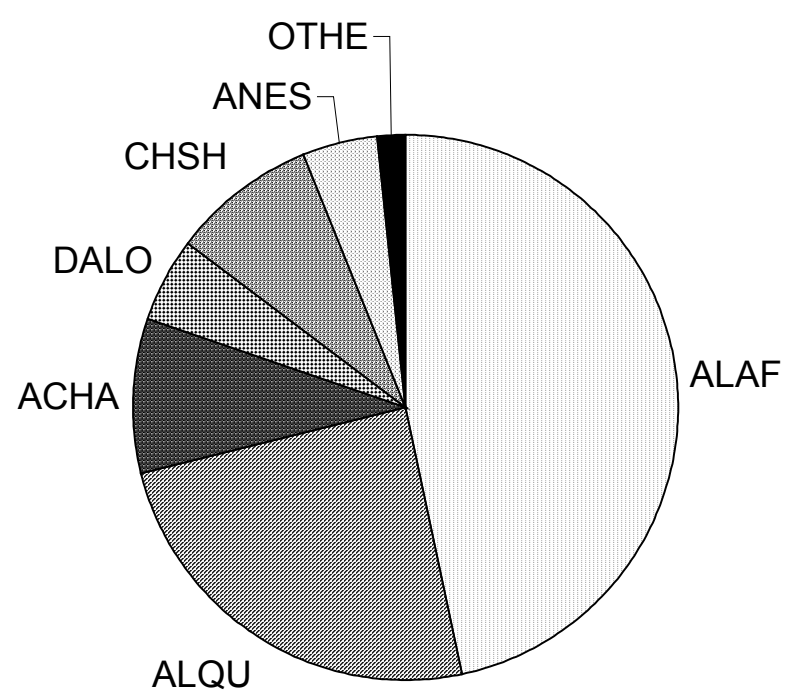

Fig. 2. Relative abundance of Cladocera taxa recovered from sediments of the recent and pre-industrial periods. Legend: ALAF: Alona affinis; ALQU: Alona quadrangularis; ACHA: Acroperus harpae; DALO: Daphnia longispina group; $\mathrm{CHSH}$ : Chydorus sphaericus; ANES: Alonella excisa; OTHE: other taxa.

The first two PCA axes explain as a whole $63.7 \%$ of the total variance (Fig. 4). The first axis, which explains $39.3 \%$ of the total variance, separates lakes rich in Alona affinis (lakes Campo, Capezzone Variola Superiore and Variola Inferiore) from lakes with $A$. quadrangularis, $A$. rectangula and Chydorus sphaericus 
(particularly Sfondato and Grande, the two most acidic lakes, with water $\mathrm{pH}=5.58$ and 5.73, respectively, cfr. Tab.1). The second axis is related to the species Acroperus harpae (lakes Pojala, Paione Superiore, Matogno and Boden Inferiore, lakes which are all relatively deep and large; cfr. Tab. 1).

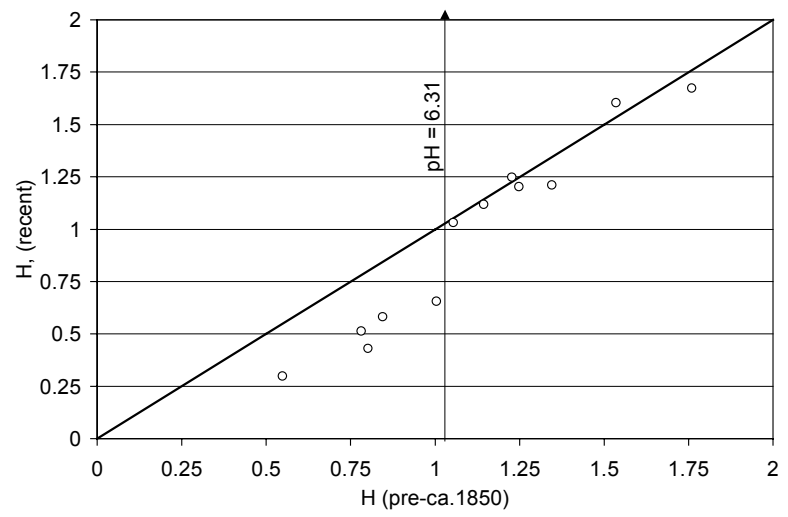

Fig. 3. Shannon-Weaver diversity index of Cladocera: comparison of communities of the recent and pre-industrial periods. The vertical arrow separates lakes with $\mathrm{pH}<6.31$ from the others.

Tab. 2. Numerical analysis of Cladocera communities of 15 lakes in the Italian Alps reconstructed from recent sediments. Eigenvalues and percent of variance explained by the first two PCA axes.

\begin{tabular}{lcc}
\hline & First axis & Second axis \\
\hline Eigenvalues & 0.39 & 0.24 \\
Cumulative \% variance of species & 39.3 & 63.7 \\
\hline
\end{tabular}

Tab. 3. Numerical analysis of cladoceran taxa and environmental parameters in the recent sediments. Eigenvalues and percent of variance explained by the first two RDA axes.

\begin{tabular}{lcc}
\hline & First axis & Second axis \\
\hline Eigenvalues & 0.47 & 0.23 \\
Cumulative \% variance of species & 51.4 & 76.7 \\
\hline
\end{tabular}

Detrended canonical analysis (DCA) revealed short gradient lengths, therefore we applied redundancy analysis to the data (Fig. 5). The total variance explained by the first two RDA axes is $76.7 \%$. The first axis, explaining $51 \%$ of the total cumulative variance species-environment relates to $\mathrm{pH}$, and chemical variables associated to it $\left(\mathrm{Ca}, \mathrm{Mg}\right.$, and $\left.\mathrm{SO}_{4}\right)$, as well as total phosphorus. Alona affinis is the species most related to the horizontal axis. The fact that $\mathrm{pH}$-related parameters and TP refers to the same axis might reflect the socalled "low pH-induced ultra-oligotrophication" of alpine lakes (Fott et al. 1994). Almer et al. (1978) suggested that if a lake is acidified to $\mathrm{pH}$ 6-5 it loses phosphorus due to the precipitation of phosphate with aluminium.

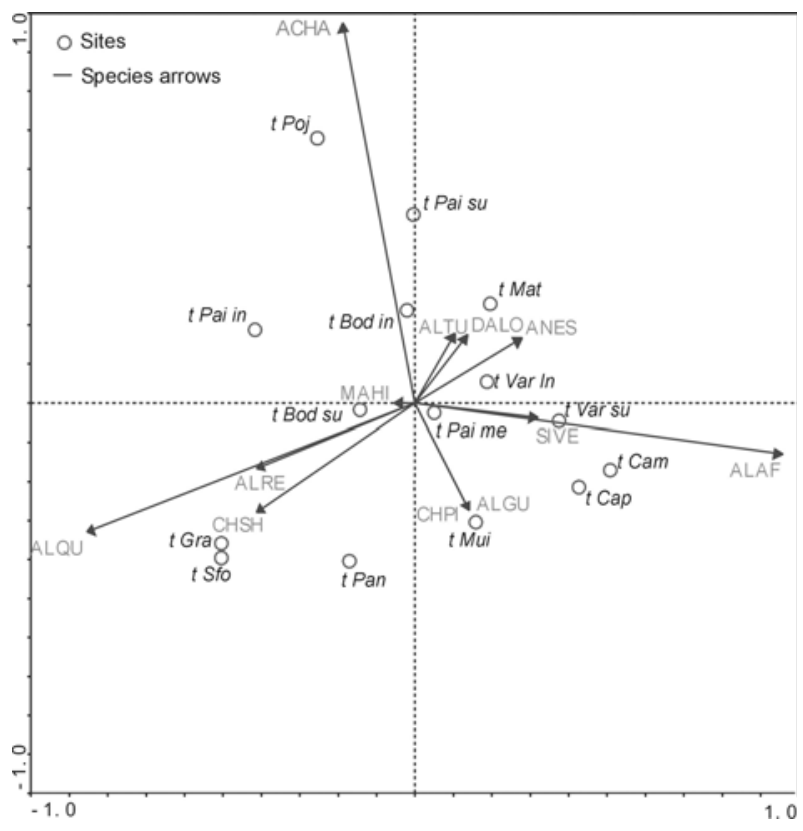

Fig. 4. PCA ordination diagram of Cladocera taxa in the surface sediments of 15 Italian lakes. Species acronyms: ACHA: Acroperus harpae; ALTU: Alona guttata tubercolata; DALO: Daphnia longispina group; ANES: Alonella excisa; SIVE: Simocephalus vetulus; ALAF: Alona affinis; ALGU: Alona guttata; CHPI: Chydorus piger (Paralona pigra; Smirnov 1996); CHSH: Chydorus sphaericus; ALRE: Alona rectangula; ALQU: Alona quadrangularis; MAHI: Machrotrix hirsuticornis.

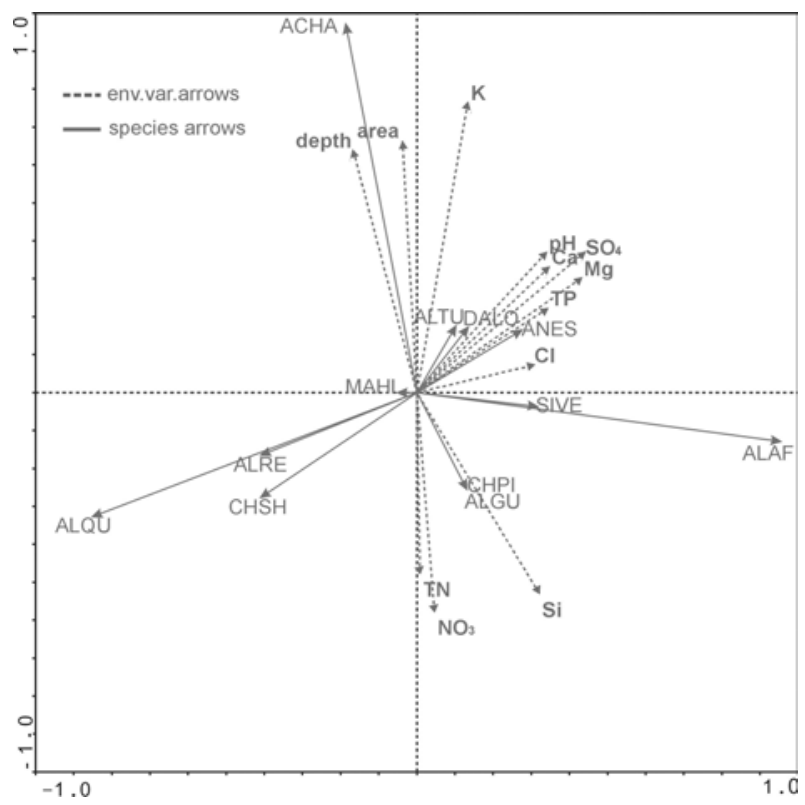

Fig. 5. RDA ordination diagram of environmental variables and Cladoceran taxa from surface sediments of 15 Italian alpine lakes of the EMERGE Project. Species acronyms as in figure 4.

Although not confirmed by others (Schindler 1988) this hypothesis hold on for lakes in the Tatra Mountains, where acidification that shifted $\mathrm{pH}$ to values lower than 
Tab. 4. Presence (P) or absence (A) of Arctodiaptomus alpinus and Daphnia longispina in relation to $\mathrm{pH}$ and fish introduction $(\mathrm{A}=$ absent; $\mathrm{P}=$ Present; $\mathrm{JP}=$ introduced in 2000 $\mathrm{AD})$.

\begin{tabular}{lccccc}
\hline Lake & $\mathrm{pH}$ & A. alpinus & Fish & \multicolumn{2}{c}{ Daphnia longispina } \\
\cline { 5 - 6 } & & & & (recent) & (past) \\
\hline Sfondato & 5.58 & $\mathrm{~A}$ & $\mathrm{~A}$ & $\mathrm{~A}$ & $\mathrm{~A}$ \\
Grande & 5.73 & $\mathrm{~A}$ & $\mathrm{~A}$ & $\mathrm{~A}$ & $\mathrm{P}$ \\
Paione Superiore & 3.02 & $\mathrm{~A}$ & $\mathrm{~A}$ & $\mathrm{P}$ & $\mathrm{P}$ \\
Variola Inferiore & 6.21 & $\mathrm{~A}$ & $\mathrm{~A}$ & $\mathrm{P}$ & $\mathrm{P}$ \\
Variola Superiore & 6.31 & $\mathrm{P}$ & $\mathrm{P}$ & $\mathrm{A}$ & $\mathrm{P}$ \\
Muino & 6.42 & $\mathrm{~A}$ & $\mathrm{~A}$ & $\mathrm{P}$ & $\mathrm{P}$ \\
Paione Medio & 6.53 & $\mathrm{P}$ & $\mathrm{A}$ & $\mathrm{A}$ & $\mathrm{A}$ \\
Paione Inferiore & 6.65 & $\mathrm{P}$ & $\mathrm{A}$ & $\mathrm{P}$ & $\mathrm{P}$ \\
Capezzone & 6.83 & $\mathrm{~A}$ & $\mathrm{P}$ & $\mathrm{P}$ & $\mathrm{P}$ \\
Panelatte & 7.11 & $\mathrm{~A}$ & $\mathrm{P}$ & $\mathrm{P}$ & $\mathrm{P}$ \\
Pojala & 7.19 & $\mathrm{~A}$ & $\mathrm{P}$ & $\mathrm{A}$ & $\mathrm{A}$ \\
Campo IV & 7.35 & $\mathrm{P}$ & $\mathrm{A}$ & $\mathrm{A}$ & $\mathrm{A}$ \\
Boden Superiore & 7.81 & $\mathrm{P}$ & $\mathrm{P}$ & $\mathrm{A}$ & $\mathrm{P}$ \\
Matogno & 7.96 & $\mathrm{~A}$ & $\mathrm{~A}$ & $\mathrm{P}$ & $\mathrm{P}$ \\
Boden Inferiore & 7.98 & $\mathrm{P}$ & $\mathrm{A}$ & $\mathrm{P}$ & $\mathrm{P}$ \\
\hline
\end{tabular}

6.3 brought about a decrease of available phosphorus, and of chlorophyll concentration, to very low or extremely low levels (Vihnálek et al. 1994). The extreme depletion of zooplankton in these lakes was therefore explained by means of starvation consequent to ultraoligotrophication.

The second axis, which is related to A. harpae, is correlated with lake area, maximum depth, and potassium concentration; in fact, larger and deeper lakes tend to have higher potassium concentrations (Tab. 1), being this ion a typical bedrock weathering product (Wögrath \& Psenner 1995). On the other hand, Chydorus piger and Alona guttata tend to relate more to silica and nitrogen concentrations. At one extreme of the vertical axis is L. Pojala, the largest, deepest lake, with the highest potassium and the lowest total nitrogen and nitrate concentrations (cfr. Tab.1); on the other extreme is L. Panelatte, a shallow (4 $\mathrm{m}$ depth), relatively small $\left(0.56 \mathrm{~km}^{2}\right)$ lake, among the most rich in nitrogen and silica.

A comparison of the recent $(\mathrm{t})$ and pre-ca 1850 (b) Cladocera assemblages of the lakes allowed a reconstruction of three major directions of change, i.e. 1) toward Acroperus harpae (L. Paione Superiore and L. Matogno); 2) toward Alona affinis (Variola and Boden lakes); and 3) toward $A$. quadrangularis- $A$. rectangulaC. sphaericus (L. Sfondato, the most acidic lake, and L. Panelatte, the second for nitrogen concentration). Little or no change was observed in the other lakes.

Although not taken into account among the "environmental variables" for numerical analysis, the introduction of fish in mountain lakes is very important for zooplankton abundance and community structure, and particularly for the presence of Daphnia longispina (Cammarano \& Manca 1997). We did not found Daph- nia neither in plankton nor in the recent sediments of those lakes where fish had been regularly introduced. In two cases only (L. Capezzone and L. Paione Inferiore) we found Daphnia despite the fish presence, probably because the introduction had been almost in coincidence with our sampling, so the effects were not yet detectable (Tab. 4). Daphnia was never found in Lake Paione Medio, probably because of the very low retention time of this lake (Cammarano \& Manca 1997). No remains of D. middendorffiana were recovered from the sediments of Lake Campo IV, the lake from which this species was described in the past (Ferrari 1967).

Surprisingly, Daphnia longispina was very abundant in the zooplankton of Lake Paione Inferiore, from which it had disappeared, along with most zooplanktonic taxa, after fish introduction during the 90s (Cammarano \& Manca 1997). The introduction was suspended between 1996 and 1999, mainly because the lake biota was so depleted that fish died of starvation.

A comparison of the present situation with that found by Cammarano \& Manca (1997) and with the "original one" reported by Tonolli (1949) (all data referring to a September sampling) clearly shows that Daphnia numbers are at present comparable with those found in the original, "pristine" community of the lake, while the level of abundance of Arctodiaptomus alpinus, is yet lower than in the past (Fig. 6). A further indication of a general enrichment of the lake biota after 4 years of no fish introduction comes from data on benthic macroinvertebrates. Ephemeroptera, present in low numbers only in the inlet waters in 1994, represents in 2000 the $50 \%$ of the total (Ephemeroptera + Plecoptera + Trichoptera); in addition, they appear for the first time in the outlet. Although being not yet present, they might potentially colonize the lake in the near future (Boggero \& Denis 2003). 


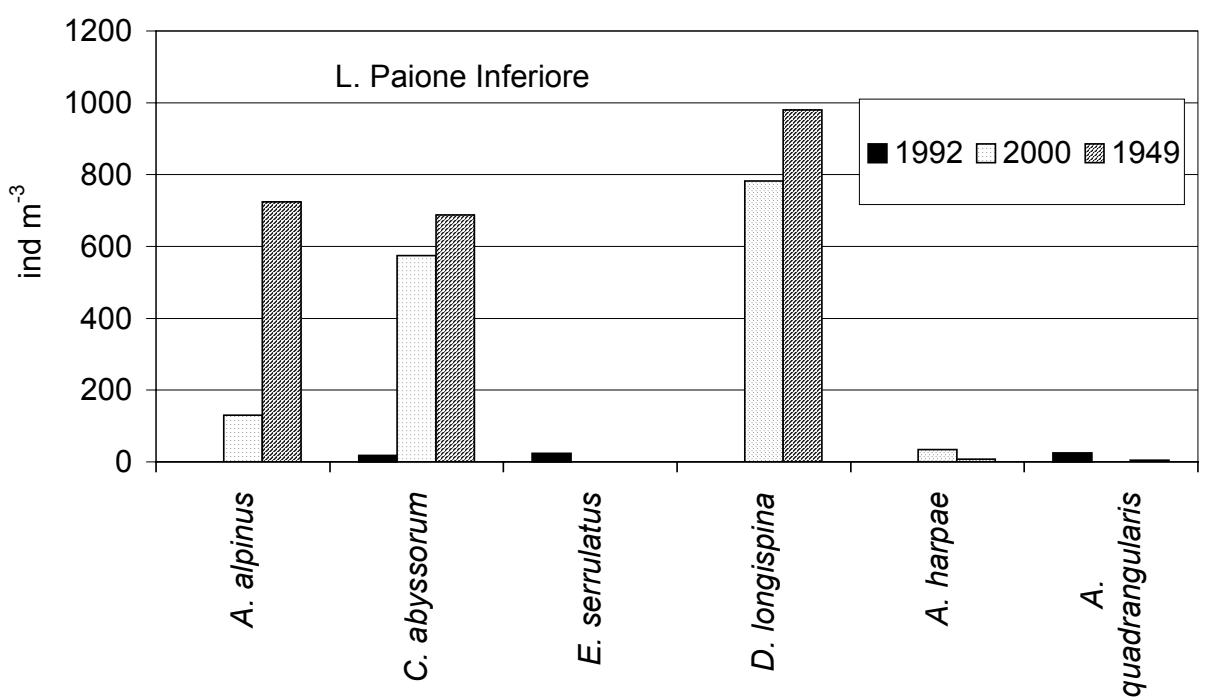

Fig. 6. Crustacean zooplankton of Lake Paione Inferiore: comparison of the community before (1948) and after (1992) fish introduction and of the most recent one (2000 AD), after fish introduction was suppressed.

\section{CONCLUSIONS}

The results of this study suggest the possibility of associating some cladoceran taxa to $\mathrm{pH}$ or $\mathrm{pH}$-related environmental parameters as well as to total phosphorus concentrations. The two environmental variables relate to the same RDA axis and this can be interpreted as a further evidence of a $\mathrm{pH}$-driven ultraoligotrophication of these remote environments.

Arctodiaptomus alpinus was not found in the plankton of lakes with water $\mathrm{pH}<6.21$, thus confirming the sensitivity of this species to acidification of atmospheric origin. On the other hand, the distribution of Daphnia seems also influenced by regular fish introduction. As fish were not introduced between 1996 and 1999, Daphnia longispina re-colonised L. Paione Inferiore, where in 1992-1993 only rotifers and a few Cyclops were found (Cammarano \& Manca 1997).

The re-colonisation can be explained by regarding the Paione lakes as a cascade system, where a transport of ephippia from the upper Lake Paione Superiore to the lower L. Paione Inferiore is certainly possible through the outlet. Most probably, L. Paione Superiore represents the Daphnia sink, L. Paione Medio the Arctodiaptomus sink, and L. Paione Inferiore the Cyclops sink (Cammarano \& Manca 1997). However, being Daphnia in these lakes a cyclical parthenogenetic species, able to produce ephippia at the end of the growing season, a recolonisation can be related to the knowledge that the sediments act as an "egg bank" for these taxa from which new populations can start again to develop from the hatching of ephippial eggs (Hairston 1992). The most acidic lakes (pH between 5.6 and 5.7) are well separated from the others in terms of community composition, being Alona quadrangularis, A. rectangula, and Chydorus sphaericus the most represented species.
Only in lakes with $\mathrm{pH}<6.3$ (Fig. 3) diversity is at present lower than that of the pre-industrial period. The loss of diversity is mainly due to the disappearance of rare species.

A clear transition toward acidic species is evident only in two cases, i.e. in L. Sfondato, the most acidic one, and in L. Panelatte, which is at present the second lake with the highest nitrogen concentration.

\section{ACKNOWLEDGMENTS}

We would like to thank A. Marchetto for helping us in using the program CANOWIN, A. Cattaneo, J. Fott and P. Guilizzoni and an anonymous referee for the revision of the manuscript.

\section{REFERENCES}

Almer, B., W. Dickson, C. Ekström \& E. Hörnström. 1978 Sulphur pollution and the aquatic ecosystems. In: Nriagu, J.O. (Ed.). Sulphur in the environment, part II: Ecological impacts. Wiley, New York: 271-311.

Boggero, A. \& S. Denis. 2003. First results from the EMERGE Project on Ephemeroptera, Plecoptera and Trichoptera of three cascade lakes (Paione lakes, Northwestern Italy). J. Limnol.: submitted.

Cammarano, P. \& M. Manca. 1997. Studies on zooplankton in two acidified high mountain lakes in the Alps. Hydrobiologia, 356: 97-109.

Charles, D.F., J.P. Smol \& D.R. Engstrom. 1994. Paleolimnology approach to biological monitoring. In: Loeb, S.L. \& A. Specie (Eds). Biological monitoring of Aquatic Systems. CRC Press, Boca Raton, Fl (USA): 233-293.

Ferrari, I. 1967. Considerazioni sistematiche ed ecologiche sulla Daphnia middendorffiana di un lago dell'Alta Val Bognanco. Mem. Ist. ital. Idrobiol., 22: 61-80.

Fott, J., M. Pražáková, E. Stuchlík \& Z. Stuchlícovà. 1994. Acidification of lakes in Sumava (Bohemia) and in the High Tatra Mountains(Slovakia). Hydrobiologia, 274: 3747.

Frey, D.G. 1958. The later-glacial cladoceran fauna of a small lake. Arch. Hydrobiol., 54: 209-275. 
Frey, D.G. 1960. The ecological significance of cladoceran remains in lake sediments. Ecology, 41: 684-699.

Frey, D.G. 1986. Cladocera analysis, Handbook of Holocene Palaeoecology and Palaeohydrology. J. Wiley and Sons. Ltd: 667-692.

Guilizzoni, P., A. Lami \& A. Marchetto. 1993. The sediment core analysis in high altitude lakes of Central Alps: comparison of three inferring- $\mathrm{pH}$ techniques and effect of temperature on lake acidification. Mem. Ist. ital. Idrobiol., 52: 387-400.

Guilizzoni, P., A. Marchetto, A. Lami, N. Cameron, P.G. Appleby, N.L. Rose, Ø. Schnell, C.A. Belis, A. Giorgis, \& L. Guzzi. 1996. The environmental history of a mountain lake (Lago Paione Superiore) Central Alps, Italy, for the last c. 100 years: a multidisciplinary, palaeolimnological study. J. Paleolimnol., 15: 245-264.

Hairston, G.N. 1992. Zooplankton egg banks as biotic reservoirs in changing environments. Limnol. Oceanogr., 41: 1087-1092

Lami, A., N. Cameron \& A. Korhola (Eds). 2000. Paleolimnology and ecosystem dynamics at remote European Al- pine lakes (Mountain Lakes Research programme, MOLAR). J. Limnol., 59: 119 pp.

Schindler, D.W. 1988. Experimental studies of chemical stressors on whole lake ecosystems. Verh. int. Ver. Limnol., 23: 11-41.

Smirnov, N.N. 1996. Cladocera: Chydorinae and Saycinae of the world. In: Dumont H.J., (Ed.), Guides to the identification of the Microinvertebrates of the Continental waters of the World. SBP Academic Publishing: 203 pp.

Ter Braak, C.J.F., R.H.G. Jongman \& O.F.R. Van Tongeren. 1986. Data analysis in community and landscape ecology. Chap. 5, Ordination. Pudoc, Wageningen: 91-172.

Tonolli, V. 1949. Gli alti laghi della Val Bognanco. Parte II. Mem. Ist. ital. Idrobiol.,: 5: 39-93.

Vihnálek, V., J. Fott \& J. Kopáček. 1994. Chlorophyll-phosphorus relationship in acidified lakes of the High Tatra Mountains (Slovakia). Hydrobiologia, 274: 171-177.

Wögrath, S. \& R. Psenner. 1995. Seasonal, annual and longterm variability in the water chemistry of a remote high mountain lake: acid rain versus natural changes. Water, Air and Soil Pollution, 85: 359-364.

Received: June 2002

Accepted: September 2002 